\title{
Ovine White-Liver Disease (OWLD) in Norway: Clinical Symptoms and Preventive Measures
}

\author{
By Martha J. Ulvund and Markus Pestalozzi
}

State Veterinary Research Station for Small Ruminants, Sandnes, and State Agricultural Research Station, Særheim, 4062 Klepp, Norway.

\begin{abstract}
Ulvund M. J. and M. Pestalozxi: Ovine white-liver disease (OWLD) in Norway: Clinical symptoms and preventive measures. Acta vet. scand. 1990, 31, 53-62. During 6 years, altogether 458 twin lambs of the Dala and Rygja breeds with their dams were put on ovine white-liver disease (OWLD) pastures which were moderately, heavily or not cobalt fertilized, or on control pastures $15 \mathrm{~km}$ apart. Groups of lambs were untreated, regularly dosed with Co sulphate or vitamin $B_{12}$, dosed with $\mathrm{Co}$ pellets, copper oxide needles $(\mathrm{CuO})$, selenium pellets or $\mathrm{Co}-\mathrm{Se}-\mathrm{Cu}$ glass boli, or had access to Co enriched salt lick. Clinical symptoms in untreated lambs included varying degree of reduced weight gain or loss of weight appearing after 6-12 weeks on pasture, at an age of 10-15 weeks. Additional symptoms were seen 2-4 weeks later, including inappetence, listlessness, and often serous eye discharge and crusty ears. Of the untreated lambs on OWLD pastures $18 \%$ died or were eutanized because of OWLD. The condition was preventable by Co or $B_{12}$ administration, which yielded an average increase of mid Sept. live weights of between 8 and $17 \mathrm{~kg}$. Co fertilization of pastures, use of Co enriched salt lick, or dosing with Co pellets are recommended under practical circumstances. The lambs grazing control pastures were on average $17 \mathrm{~kg}$ heavier by mid Sept. than the OWLD lambs. They showed some weight increase on extra Co supply.
\end{abstract}

sheep; cobalt deficiency; $B_{12}$ deficiency; illthrift; prevention.

\section{Introduction}

Illthrift among grazing lambs on certain cultivated pastures in south-western Norway was described as a disease resembling ovine white-liver disease (OWLD), a condition with hepatic damage in cobalt/vitamin $\mathrm{B}_{12}$ deficient lambs (Ulvund \& Øverås 1980, Ulvund 1983). On affected pastures, the lambs grew well up to mid July, when they were 3-4 months of age, while weight gain during late summer was poor. This article describes the clinical symptoms of the disease as well as the effects of preventive measures undertaken during a 6-year period (1981-86).

\section{Materials and methods}

Survey of preventive measures, symbols used, pastures, lambs and lamb groups are shown in Tables 1 and 2. The OWLD pastures (S) totally comprised 1.4 ha of cultivated land, while the control pastures $(\mathrm{H})$ included 3 neighbouring plots $(2.7 \mathrm{ha} / \mathrm{plot})$ of fertilized natural pastures, all situated $15 \mathrm{~km}$ away from the OWLD pastures. Lambs had been thriving well for years on the $\mathrm{H}$ pastures. Botanical and chemical composition of the pastures is given elsewhere (Ulvund \& Pestalozzi in press).

Altogether 458 twin lambs of the Dala and Rygja breeds with their 229 dams were in- 
Table 1. Survey of preventive measures performed in experimental lambs, and symbols used. Lambs designated S were grazing OWLD pastures at Særheim, while those grazing disease free pastures at Høyland were designated $\mathrm{H}$.

\begin{tabular}{|c|c|}
\hline Symbol & Explanation \\
\hline $\mathbf{S}$ & Not treated. \\
\hline $\mathrm{SCoSO}_{4}$ & Cobalt sulphate given weekly by mouth at a dose of $33 \mathrm{mg} \mathrm{CoSO} 4 \cdot 7 \mathrm{H}_{2} \mathrm{O}(7 \mathrm{mg} \mathrm{Co})$ \\
\hline $\mathrm{SB}_{12}$ & $\begin{array}{l}\text { Vitamin } B_{12} \text {-depot (hydroxocobalamin, NYCO, Norway) given at a dose of } 2 \mathrm{mg} \text { im every } \\
\text { third }(1981,1984) \text { or second }(1982,1983,1985) \text { week. }\end{array}$ \\
\hline SCopell & $\begin{array}{l}\text { Permaco Cobalt Pellets (ICI, Tasman Vaccine Lab., UK) dosed on June } 251984 \text { and July } \\
11985 .\end{array}$ \\
\hline $\mathrm{SCuO}$ & $\begin{array}{l}\text { Copper oxide needles (Copporal, } 2 \mathrm{~g} \text {, Beecham Animal Health, UK) dosed at pasture outlet } \\
\text { (May 15) } 1984 \text {. }\end{array}$ \\
\hline $\mathrm{SCoSeCu}$ & $\begin{array}{l}\text { Cobalt-selenium-copper glass boli (CoSeCure, Chance Pilkington Ltd., The Wellcome } \\
\text { Foundation Ltd., UK) dosed on July } 11985 .\end{array}$ \\
\hline SSe & $\begin{array}{l}\text { Selenium pellets (Permasel, } 5 \% \text {, ICI, Tasman Vaccine Laboratory, UK, Bury St. Edmunds, } \\
\text { Suffolk) dosed on July } 11985 \text {. }\end{array}$ \\
\hline SColick & $\begin{array}{l}\text { Access to sodiumchloride lickstone }(39 \% \mathrm{Na}, 0.07 \% \mathrm{Fe}) \text { added (mg/kg stone) Co ( } 21), \mathrm{Mn} \\
(182), \mathrm{Zn}(113), \mathrm{I}(25.5) \text {, and Se (20.4). Manufactured by J. Østensjø \& Co. A/S, Haugesund, } \\
\text { Norway. }\end{array}$ \\
\hline SCo & Lambs grazing moderately cobalt fertilized OWLD pastures. \\
\hline SCot & Lambs grazing heavily Co fertilized OWLD pastures. \\
\hline $\mathbf{H}$ & Not treated. \\
\hline HCopell & Permaco Co pellets dosed to single H twins on June 221981 and June 61983. \\
\hline HColick & Access to Co lickstone. \\
\hline HCo & Grazing Co fertilized disease free pastures. \\
\hline
\end{tabular}

cluded. The individual groups were matched with regard to age, sex, breed and live weight (lw) in early May each year. On average, the Dala/Rygja ratio within the groups was 1.3. The lambs were born between Apr.5 and May 1, mean birth date was Apr. 19. Pasture outlet was between May 10 and 20, and the lambs grazed with their dams until the end of the experimental period in Sept./ Oct., when most of them were slaughtered. Mean number of days at pasture was 143 . Mean pasture area per ewe with twins was between 750 and $800 \mathrm{~m}^{2}$ on the $S$ pastures, and between 1900 and $2700 \mathrm{~m}^{2}$ on the $\mathrm{H}$ pastures. This setup was designed to compensate for better growth of grass on the $S$ pastures. Each year, the $S$ pastures were overgrown and had to be cut at the end of June. During 2 years, decreasing amounts of grass in later part of the grazing period led to the removal of the untreated $S$ group on Sept. 21 1981, and the SCopell group on Aug. 151985.

All lambs were weighed weekly, whereas the eves were weighed monthly. The lambs were examined clinically in connection with weighing, sampling and dosing. Blood samples were taken and examined as recorded elsewhere (Ulvund in press a). Lambs with severe OWLD were taken to the laboratory for treatment or euthanasia and autopsy, and in 1982, lambs from 3 groups were killed and autopsied at various intervals throughout the grazing period (Ulvund, inpress b).

The ewes were given anthelmintic treatment with either fenbendazole (Panacur ${ }^{\circledR}$, Hoechst, UK) or albendazole (Valbazen ${ }^{\circledR}$, 
Table 2. Survey of pastures and number of lambs (n) used within each group every year. Symbols are explained in Table 1. Number of lambs which dies or were eutanized due to OWLD is given in brackets.

\begin{tabular}{|c|c|c|c|c|c|c|}
\hline \multirow{3}{*}{ Year } & \multicolumn{4}{|c|}{$\begin{array}{l}\text { Sxrheim pastures (S) } \\
\text { (OWLD associated) }\end{array}$} & \multicolumn{2}{|c|}{$\begin{array}{c}\text { Høyland pastures }(\mathrm{H}) \\
\text { (disease free) }\end{array}$} \\
\hline & \multicolumn{2}{|c|}{$\begin{array}{c}\text { Not cobalt } \\
\text { fertilized (S) }\end{array}$} & \multicolumn{2}{|c|}{$\begin{array}{c}\text { Cobalt } \\
\text { fertilized (SCo) }\end{array}$} & \multirow[b]{2}{*}{ Group } & \multirow[b]{2}{*}{$\mathrm{n}$} \\
\hline & Group & $\mathrm{n}$ & Group & $\mathrm{n}$ & & \\
\hline 1981 & $\begin{array}{l}\mathrm{S} \\
\mathrm{SCoSO}_{4} \\
\mathrm{SB}_{12} \\
\end{array}$ & $\begin{array}{l}8(4) \\
8 \\
8 \\
\end{array}$ & SCo & 12 & $\begin{array}{l}\text { H } \\
\text { HCopell }\end{array}$ & $\begin{array}{l}20 \\
20\end{array}$ \\
\hline 1982 & $\begin{array}{l}\mathrm{S} \\
\mathrm{SB}_{12}\end{array}$ & $\begin{array}{l}12(2) \\
12\end{array}$ & SCo & 12 & $\mathbf{H}$ & 30 \\
\hline 1983 & $\begin{array}{l}\mathrm{S} \\
\mathrm{SB}_{12} \\
\end{array}$ & $\begin{array}{c}16(4) \\
8 \\
\end{array}$ & SCo & 12 & $\begin{array}{l}\text { H } \\
\text { HCopell } \\
\end{array}$ & $\begin{array}{l}24 \\
24 \\
\end{array}$ \\
\hline 1984 & $\begin{array}{l}\text { S } \\
\text { SB }_{12} \\
\text { SCopell } \\
\text { SCuO }\end{array}$ & $\begin{array}{l}6(1) \\
6 \\
8 \\
6\end{array}$ & SCo & 12 & $\mathbf{H}$ & 24 \\
\hline 1985 & $\begin{array}{l}\text { S } \\
\text { SCopell } \\
\mathrm{SB}_{12} \\
\text { SCoSeCu } \\
\text { SSe } \\
\end{array}$ & $\begin{array}{l}6 \\
4 \\
4 \\
6 \\
6\end{array}$ & SCo+ & 6 & $\mathbf{H}$ & 24 \\
\hline 1986 & $\begin{array}{l}\text { S } \\
\text { SColick }\end{array}$ & $\begin{array}{l}12 \\
12\end{array}$ & $\begin{array}{l}\text { SCo } \\
\text { SCot }\end{array}$ & $\begin{array}{l}6 \\
6\end{array}$ & $\begin{array}{l}\text { H } \\
\text { HCo } \\
\text { HColick }\end{array}$ & $\begin{array}{l}24 \\
24 \\
24\end{array}$ \\
\hline Sum & & 148 & & 72 & & 238 \\
\hline
\end{tabular}

One third of the OWLD pastures (S) was fertilized with cobalt $\left(\mathrm{CoSO}_{4} \cdot 7 \mathrm{H}_{2} \mathrm{O}, 1 \mathrm{~kg} / \mathrm{ha}\right)$ in early May for three years (1980-1982, SCo). Half of this plot was fenced off and refertilized ( $1 \mathrm{~kg} / \mathrm{ha})$ in 1985 and 1986 (SCo+). In 1986, the unfertilized S pasture was divided in two parts, and Co lick was placed on one (SColick). One of the control (H) pastures was Co fertilized ( $2 \mathrm{~kg} / \mathrm{ha})$ in $1986(\mathrm{HCo})$, and Co lick was placed on one (HColick).

NOVO, Denmark), and also vaccinated against clostridial diseases $2-6$ weeks before lambing each year $\left(\right.$ Ovivac $^{\circledR}$, Hoechst or Trivexin $^{\circledR}$, Welcome, UK). The lambs were treated prophylactically against coccidiosis with sulphadimidine by mouth $(16 \%, 1$ $\mathrm{ml} / \mathrm{kg} \mathrm{lw}$ ) on day 12,14 and 16 after outlet. Faecal samples were taken 2-4 times at dif- 
ferent intervals throughout grazing, and examined for coccidia and helminthic eggs according to routine methods. The lambs were treated 5 times with either fenbendazole or albendazole, the first time after 2-3 weeks on pasture, and then after 2, 3, 4 and 4 weeks.

Preventive measures are shown in Table 1. Both twins were treated unless otherwise mentioned. The localization of the pellets in the forestomachs was examined at slaughter.
Results of $\mathrm{Cu}$ and $\mathrm{Se}$ dosing are reported elsewhere (Ulvund, in press c). The Co lickstone was available for the sheep throughout the entire grazing period.

Statistical testing of differences was done by Student's t-test.

\section{Results}

\section{Clinical symptoms}

Live weight (lw) curves are shown in Fig. 1,

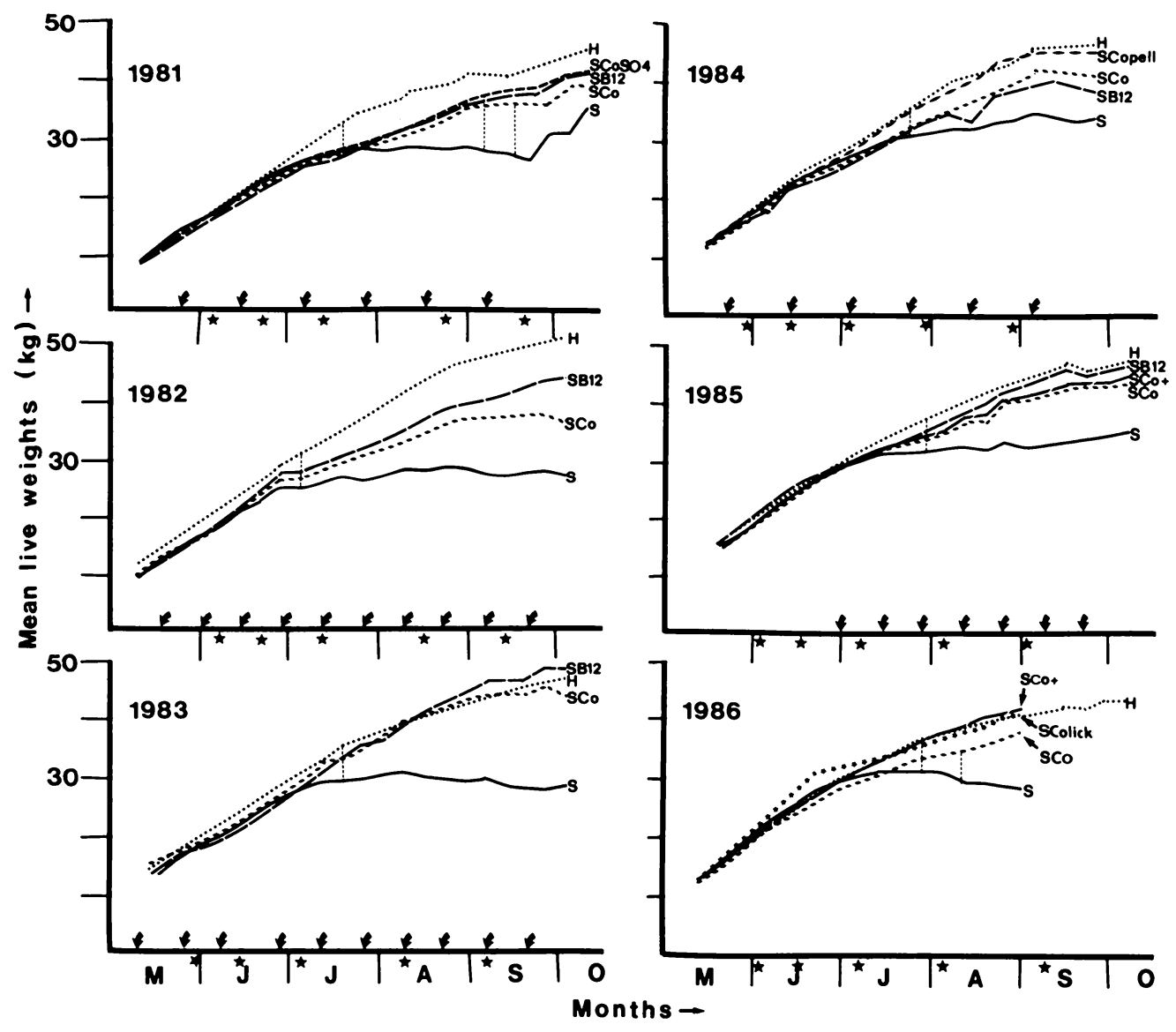

Figure 1. Mean weekly live weights $(\mathbf{k g})$ in various groups of lambs throughout the grazing period. The initial point of significant difference $(\mathrm{p}<0.05)$ between some groups are indicated by broken vertical lines. For explanation of lamb groups, see legend of Table 1 . Vitamin $\mathbf{B}_{12}$ injections $\left(\mathrm{SB}_{12}\right.$ group) are indicated by arrows, anthelmintic treatments by stars. 
Martha J. Ulvund and Markus Pestalozzi: Ovine White-Liver Disease (OWLD) in Norway: Clinical symptoms and preventive measures.

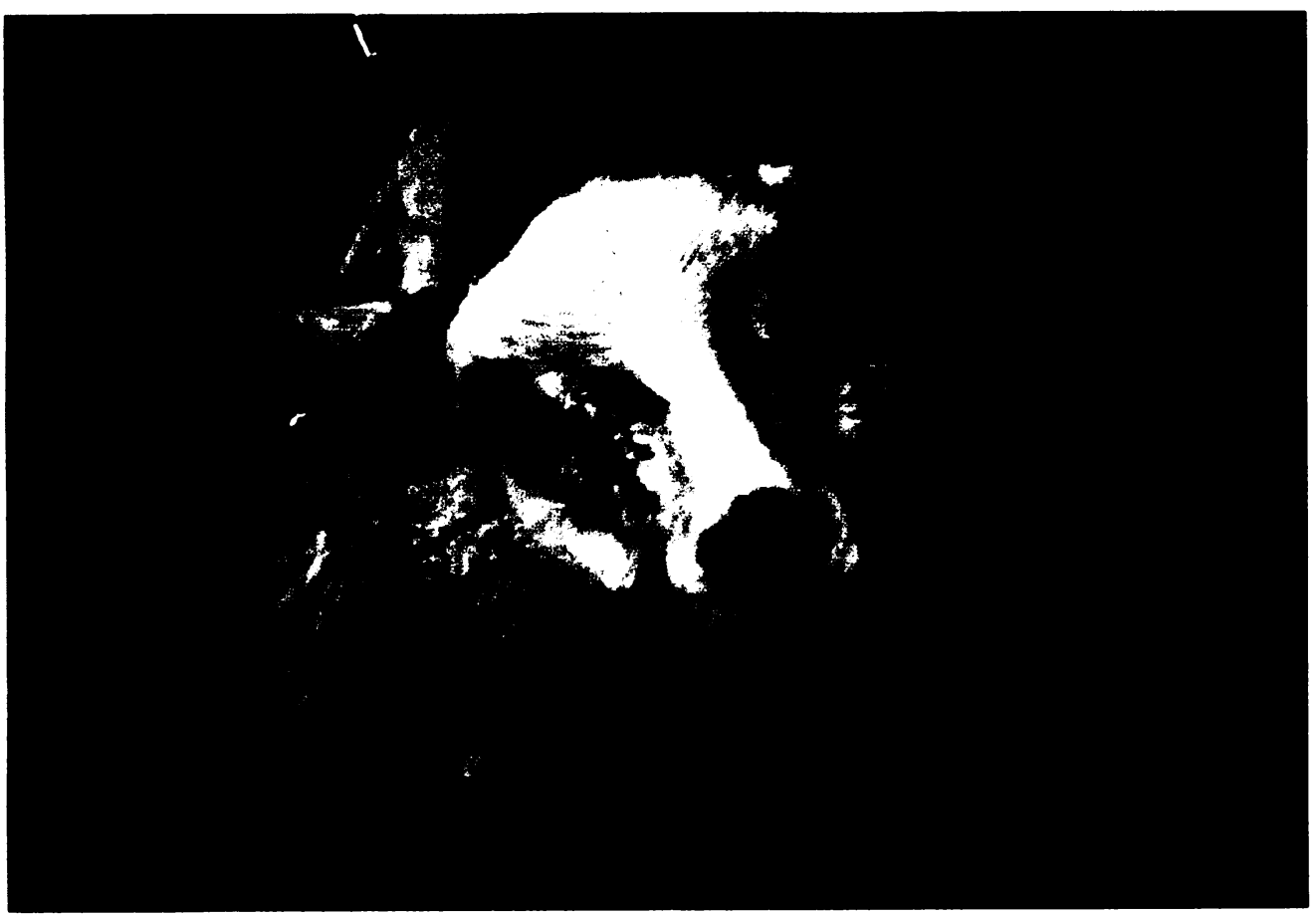

Figure 2. Typical lamb affected with OWLD, with eye serous discharge and small crusts on ears. This lamb was $22 \mathrm{~kg}$ in early July, and had the same weight by end of Sept., when it was eutanized.

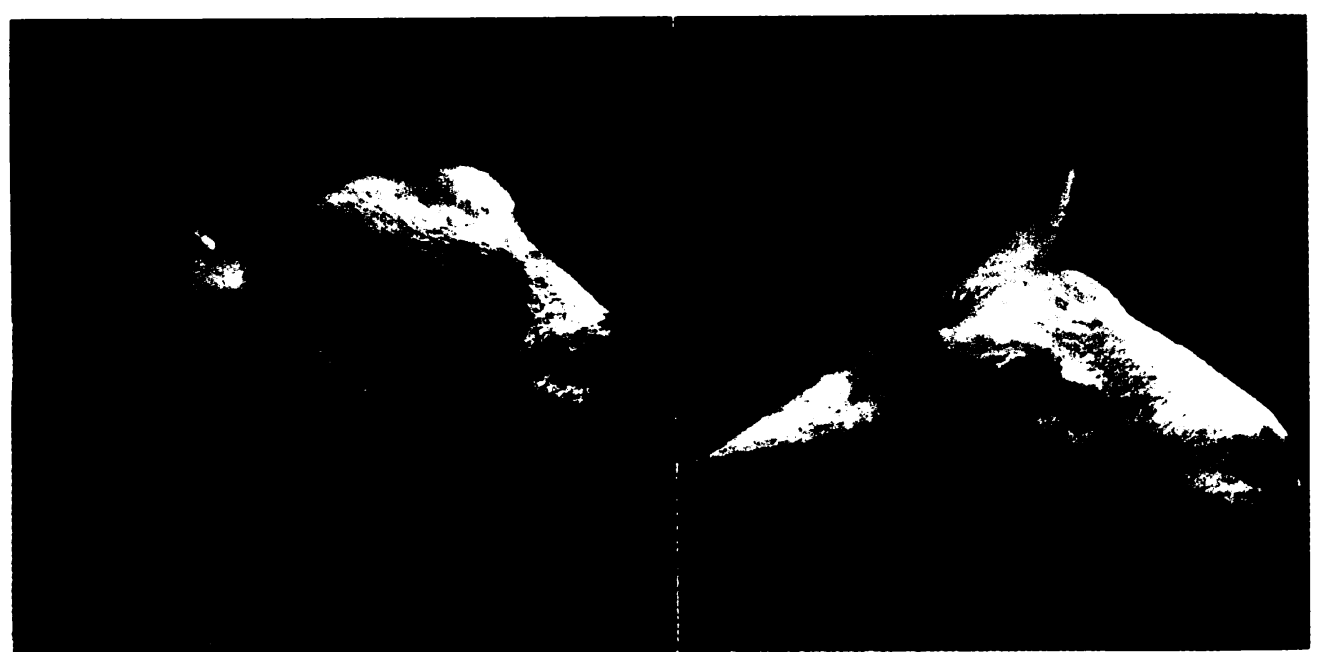

Figure 3. These lambs had the same live weight $(13 \mathrm{~kg})$ when they were put on OWLD pastures. The left lamb was untreated, and weighed $24 \mathrm{~kg}$ by mid Sept., while the right was injected every second week with vitamin $\mathrm{B}_{12}$, and was $20 \mathrm{~kg}$ heavier. 
Table 3.Growth rates ( $g /$ day) during pasture each year for the untreated lambs on OWLD pasture (S), and increases ( $g /$ day) for the other groups as compared with the $S$ group. Mean values for all years and range in mean growth rates from year to year are given within each group. For group explanation, see legend of Table 1.

\begin{tabular}{lcccccccc}
\hline & $1981^{*}$ & 1982 & 1983 & 1984 & 1985 & 1986 & Mean & Range \\
\hline $\mathrm{S}$ & 125 & 116 & 132 & 170 & 149 & 127 & 137 & $116-170$ \\
\hline $\mathrm{SCoSO}_{4}$ & 97 & - & - & - & - & - & 97 & - \\
$\mathrm{SCo}$ & 71 & 60 & 99 & 52 & 60 & 100 & 74 & $176-231$ \\
$\mathrm{SCo}+$ & - & - & - & - & 62 & 132 & 97 & $211-259$ \\
$\mathrm{SCopell}$ & - & - & - & 56 & - & - & 56 & - \\
$\mathrm{SB}_{12}{ }^{* *}$ & - & 119 & 122 & - & 74 & - & 105 & $223-254$ \\
$\mathrm{SB}_{12}{ }^{* * *}$ & 88 & - & - & 32 & - & - & 60 & $202-213$ \\
SColick $_{\mathrm{H}}$ & - & - & - & - & - & 115 & 115 & - \\
\hline
\end{tabular}

* In 1981, growth rates for all groups are given between pasture outlet and Sept. 21 , when the $S$ lambs were removed from the OWLD pastures.

** Injected with $B_{12}$ every two weeks.

*** Injected with $B_{12}$ every three weeks.

and growth rates (g/day) from pasture outlet to removal from pasture are shown in Table 3. Control lambs $(\mathrm{H})$ showed satisfactory weight gain evey year, while the untreated $\mathrm{S}$ lambs showed varying degree of reduced weight gain and loss of weight throughout grazing. The difference in mean $1 w$ between the $\mathrm{H}$ and $\mathrm{S}$ lambs was significant from between July 5 (1982) and July 29 (1985), and was between 13 and $22 \mathrm{~kg}$ (overall mean 17 kg) by mid Sept.

Reduced weekly weight gain was the first sign of the disease. Additional symptoms were seen 2-4 weeks later, in late July (1982, 1983) or early Aug. (1981, 1984-1986), and developed gradually. General features were unthrifty outlook with dry, lifeless fleece, inappetence, listlessness or a sort of tameness resulting in reluctant gait. Serous eye discharge with formation of crusts on eyelids and cheeks (Fig. 2) was seen in about $10 \%$ of the untreated $S$ lambs in late July, and in $20-50 \%$ of them in Aug.-Sept. Conjunctivae were moist and sometimes hyperaemic, although other membranes appeared pale. The ears were often diffusely reddened with dry skin and small crusts. Scurvy ears were noted in up to $50 \%$ of the untreated $\mathrm{S}$ lambs in Aug.-Sept., but some years this was seen in up to $40 \%$ of lambs from the other $\mathrm{S}$ groups, except the $\mathrm{SB}_{12}$ group which was unaffected. The most seriously affected lambs were weak, and some became dull and atactic. Blindness and convulsions were not seen during these years. The animals were afebrile, only a few had fever $\left(>40^{\circ} \mathrm{C}\right)$ in more advanced stages. Respiratory rates and pulse rates were normal, except for increased rates in the few with fever. Ruminal activity was most often reduced.

Altogether 11 untreated lambs on OWLD pastures died or were eutanized due to severe OWLD ( $18 \%$, Table 2$)$. In addition, two untreated $S$ lambs were found dead on pasture in June and July 1981, and one in June 1983, before they had developed clinical OWLD, and no cause of death was found 
(autolytic). Two lambs from the $\mathrm{SCoSO}_{4}$ group died from other reasons.

Coddidial oocyst counts were low within all groups. The anthelmintic treatment scheme resulted in moderate total mean egg counts, although a rise was seen in Aug. most years. During 4 years, the untreated $S$ lambs had higher mean number of nematode eggs per gram (EPG) in Aug. (above 1000) than the other groups, which had mean EPG below 1000. In 1983, half of the $S$ lambs had diarrhea 14 days after pasture outlet, but no correlation to oocyst counts was found. Sporadic cases of diarrhea were seen most years within all groups, but no direct cause was found.

\section{Prevention}

Extra supply of $\mathrm{Co}$, or regular $\mathrm{B}_{12}$ injections, resulted in an average increase of mid Sept. lw of between 8 and $17 \mathrm{~kg}$, as compared to untreated $\mathrm{S}$ lambs (Fig. 1).

Weekly dosing with Co sulphate gave good performance and prevention of symptoms, althrough a few lambs had crusty ears. Fertilization of pastures with Co had similar effect. The use of $1 \mathrm{~kg} \mathrm{CoSO} /$ ha for 3 years had satisfactory effect during the following 3 years. After that, the effect seemed somewhat reduced. The difference in mean $1 w$ between the SCo and SCo+ lambs in 1986 was $4 \mathrm{~kg}$ on Sept. 1 (NS).

Dosing with Co pellets resulted in satisfactory lamb growth. At slaughter, none of the $S$ lambs and 2 of the $H$ lambs $(3.5 \%)$ had lost the pellet. In mid Sept. 1984, the SCopell lambs were on average $12 \mathrm{~kg}$ heavier than the $S$ lambs $(p<0.005)$. On aug. 15 1985, when the SCopell lambs were removed from $\mathrm{S}$ pasture, they were $2 \mathrm{~kg}$ heavier than the $S$ lambs (NS).

Dosing with $B_{12}$ resulted in very good performance. The wool was soft and there were no crusty ears (Fig. 3). The use of Co lick- stone on the $\mathrm{S}$ pastures also resulted in excellent growth.

Application of extra Co to $\mathrm{H}$ lambs (HCopell, $\mathrm{HCo}, \mathrm{HColick}$ ) resulted in $2-3 \mathrm{~kg} \mathrm{lw}$ increase by end of grazing season (NS). During 1981 and 1983, the HCopell lambs gained on average $15 \mathrm{~g}$ /day more than the $\mathrm{H}$ lambs. Up to Oct. 19 1986, the HCo and HColick lambs gained 7 and $11 \mathrm{~g}$ /day more than the $\mathrm{H}$ lambs.

The adult ewes were generally in good condition on all pastures, and showed no significant differences in lw.

\section{Discussion}

The symptoms of our lambs including illthrift, serous eye discharge and crusty ears were similar to those described for OWLD by Clark et al. (1978), Sutherland et al. (1979), and Mitchell et al. (1982). Signs of acute photosensitization with oedema and swelling of ears, which were seen in a few lambs during earlier years, were not noted. The crust formation on the ears may reflect a state of chronic photosensitization. Hot swollen ears are described in the acute disease, while anaemia, emaciation and crusty ear lesions are typical in the chronic form (Clark et al. 1978, Sutherland 1978, Richards \& Harrison 1981).

Simple Co deficiency is characterized by growth retardation, emaciation, and watery eye discharge (Andrews 1971, Smith 1987), as well as tender and lifeless wool (Lee 1950). It is still unclear whether OWLD is a primary Co deficiency, or a hepatopathy against which dietary Co or injected $\mathrm{B}_{12}$ are protective (Smith 1987). The clinical symptoms are not pathognomonic for any of the diseases.

The lambs started to show reduced weight gain after 6-12 weeks on pasture, at an age of 10-15 weeks. In 21 outbreaks of OWLD, lambs aged 6-24 weeks were involved in 18, 
hoggets aged 54-58 weeks in 2, and adult ewes in 3 (Sutherland et al. (1979). Lambs around and after weaning age have been most commonly affected (Clark et al. 1978, Richards \& Harrison 1981, Mitchell et al. 1982, McLoughlin et al. 1984). Simple Co deficiency often becomes apparent when sheep graze 4-6 months on deficient forage (Blood et al. 1985). Depending on the cobalt nutrition of their dams, however, reduced lw gain may appear already from 4 weeks of age (Quirk \& Norton 1987).

Nearly all the unsupplemented $S$ lambs $(95-100 \%)$ showed reduced weight gain as compared to the $\mathrm{Co} / \mathrm{B}_{12}$ supplemented ones. One died of OWLD, while 10 were so severely affected that they had to be eutanized (18\%). Sutherland et al. (1979) reported a mean morbidity rate of OWLD in lambs within the flocks of $36 \%(6-100 \%)$, and a mortality of $15 \%(0.5-42 \%)$, while Mitchell et al. (1982) reported that morbidity varied from 20 to $100 \%$, and mortality from 8 to $15 \%$. In primary Co deficiency, corresponding figures are not easy to find, due to variations in severity and Co status of the animals. In seriously deficient regions, morbidity may reach $60 \%$, and $80 \%$ of affected lambs may die (Jensen \& Swift 1982).

The individual variation in lw within the groups, as expressed by the estimated standard deviation (sd), was between 1 and $2 \mathrm{~kg}$ at pasture outlet. By mid Sept., the sd had increased to $5-6 \mathrm{~kg}$ in the $\mathrm{H}$ group, and to $6-10 \mathrm{~kg}$ in the $S$ group. The lowest mean $\mathrm{lw}$ was associated with the largest sd. This probably both reflects a difference in susceptibility of OWLD, and that once lambs had reached a certain degree of clinical affection, they were progressively worsened.

The variation in clinical symptoms among the $\mathrm{S}$ lambs was also great. Characteristics like reduced vigour and unthriftiness were difficult to quantify, and as the most evident symptom, eye discharge, only affected a proportion of the animals, clinical diagnosis on single lambs basis was difficult. Blindness and convulsions as seen earlier (Ulvund \& Øverås 1980), were not noted. Neurological symptoms seem to appear occasionally in OWLD (Smith 1987).

When lambs are 12 weeks old, the ewe's milk yield disminishes, the grass falls off in production and quality, and effects of parasitism and fouling may appear (Willcock 1971). Our strategic anthelmintic treatment ruled out the significance of parasites as primary cause of the illthrift. The higher mean egg counts found in the untreated $S$ lambs as compared to the others may indicate a state of decreased resistance to parasitism. Some workers suggest that Co deficient ruminants have such decreased resistance (Richard et al. 1954, Andrews et al. 1970, Sutherland 1978, MacPherson et al. 1987). The occurrence of diarrhea may also reflect impaired immunity. Sporadic cases of diarrhea were also found in OWLD by Sutherland (1978) and Mitchell et al. (1982).

The effects of fouling were regarded as insignificant on the $\mathrm{H}$ pastures, but may have been of some importance on the $\mathrm{S}$ pastures, explaining some of the lw difference between the $H$ lambs and $C o / B_{12}$ supplemented $S$ lambs. The condition was unaffected by heavy stocking as long as grass availability was sufficient, and $750 \mathrm{~m}^{2}$ pasture area per ewe yielded even heavier lambs by mid Sept. (1984, 1985) than $800 \mathrm{~m}^{8}$ (1981-1983). However, when amounts of grass were decreasing, like in mid Sept. 1981 and mid Aug. 1985, weight loss was aggravated in the untreated $\mathbf{S}$ lambs, while the others were unaffected. The treated $S$ lambs had better appetite and were probably more vigorously competing for the grass.

Weight gain varied from year to year on all pastures. the $\mathrm{H}$ lambs generally had the best 
Iw gain, but even in this group, mean mid. Sept. lw varied with $8 \mathrm{~kg}$. Factors affecting growth and composition of grass may have contributed to this (Ulvund \& Pestalozzi in press). Due to the variations, it is difficult to select the most effective prevention. Of practical reasons, parallell experiments could not be performed during the same grazing season.

Lambs treated fortnightly with $B_{12}$ were 12-14 kg heavier than untreated $S$ lambs by mid Sept., while lambs treated every third week were 6-10 kg heavier. Hannam et al. (1980) found that one single injection of $1 \mathrm{mg}$ hydroxocobalamin was able to prevent growth retardation due to Co deficiency in suckling lambs for 14 weeks, but Co pellet dosed lambs grew better than the $\mathrm{B}_{12}$ dosed from 9-14 weeks after dosing. Others have found three- or four-weekly injections are necessary to prevent Co deficiency (Hogan et al. 1973, MacPherson et al. 1976, Whitelaw \& Russell 1979, Millar \& Albyt 1984). To prevent OWLD, Mitchell et al. (1982) indicated the necessity of treatment every second week, which is more in accordance with our results. Vitamin $B_{12}$ injections are too expensive and laborious for routine prevention.

To prevent Co deficiency, oral dosing of Co sulphate is recommended at the rate of 1 $\mathrm{mg} /$ day, which can be given in accumulated doses once a week (Lee 1950, Smith 1987). This dosing was effective to prevent OWLD under our circumstances. By mid. Sept., the $\mathrm{SCoSO}_{4}$ lambs were $11 \mathrm{~kg}$ heavier than the untreated ones, the difference in $\mathrm{lw}$ was significant from Sept. 7. Co sulphate dosing is too laborious as routine on pasture.

Results from 1984 showed that Co pellet dosing was effective in preventing OWLD on our pastures. Mitchell et al. (1982) also found that pellets prevented OWLD. Whitelaw \& Russell (1979) regarded the pellets to be more effective than oral Co dosing or $\mathrm{B}_{12}$ injection to prevent Co deficiency. The effectiveness of the pellets may, however, be reduced by their tendency to acquire a coating of $\mathrm{Ca}$ phosphate, or to be lost by regurgitation (Millar \& Albyt 1984). Administration of steel grinders reduce surface coating. In our case, examination of the pellets revealed some coating. Co pellets dosing may be a good alternative.

Application of Co to pasture is effective in preventing Co deficiency in sheep, although the influence of other trace elements, minerals and $\mathrm{pH}$ results in variation in effect from one area to another (Whitelaw \& Russell 1979, Smith 1987). In our case, the SCo lambs were on average $10 \mathrm{~kg}(9-16 \mathrm{~kg})$ heavier by mid. Sept. than the $\mathrm{S}$ lambs $(\mathrm{p}<$ 0.001 ). To prevent OWLD under our circumstances, 1-2 kg sulphate per ha every 3 to 4 years may be recommendable. This is largely in accordance with recommendations given to prevent Co deficiency (Blood et al. 1985).

The effect of the Co enriched salt lick was convincing. By Sept. 1, the SColick lambs were on average $13 \mathrm{~kg}$ heavier than the $S$ lambs. The difference between these 2 groups was significant from July 28 . According to Andrews (1971), such licks should contain not less than $113 \mathrm{~g} \mathrm{CoSo}_{4}$ per ton. Our lick contained $100 \mathrm{~g}$ to the ton. Some lambs may fail to lick the block. This was not the case in our experiment, where the lambs were uniform in age and lw at start of grazing. Mitchell et al. (1982) found that when Co blocks were available continuously, OWLD recurred 2 years after the initial outbreak.

The tendency of further weight increase obtained in the $\mathrm{H}$ lambs having access to extra $\mathrm{Co}$, is interesting. Held together with annual variations in $1 \mathrm{w}$, this may indicate a marginal Co situation. In slightly deficient or mar- 
ginal areas, Co deficiency can be apparent in some years and absent in others (Lee 1950). OWLD is characterized by poor performance in lambs resulting in heavy economic loss to the farmer. Under practical circumstances, the condition may be prevented by Co fertilization of pastures, dosing with Co pellets, or use of Co enriched salt lick.

\section{References}

Andrews ED, Hogan KG, Stephenson BJ, White $D A$, Elliot $D C$ : Cobalt and thiabendazole liveweight responses in grazing sheep, and their relation to the urinary excretion of methylmalonic acid. N. Z. J. agric. Res. 1970, 13, 950965.

Andrews ED: Cobalt deficiency in sheep and cattle. Bull. 180, Dep. agric. N. Z. 1971, 36 pp.

Blood DC, Radostits OM, Henderson JA, Arundel JH, Gay CC: Veterinary Medicine. 6th ed. Bailliêre Tindall, London 1985, p. 1018-1021.

Clark RG, Cornforth IS, Jones BAH, McKnight $L J$, Oliver $J$ : A condition of ovine white liver disease in lambs on irrigated pasture in South Canterburry. N. Z. vet. J. 1978, 26, 316.

Hannam RJ, Judson GJ, Reuter DJ, McLaren LD, $M c F a r l a n e ~ J D$ : Effect of vitamin $B_{12}$ injections on the growth of young merino sheep. Aust. J. agric. Res. 1980, 31, 347-355.

Hogan KG, Lorenz PP, Gibb FM: The diagnosis and treatment of vitamin $B_{12}$ deficiency in young lambs. N. Z. vet. J. 1973, 21, 234-237.

Jensen $R$, Swift $B R$ : Diseases of sheep. 2nd ed. Lea \& Febiger, Philadelphia 1982, 330 pp.

Lee HJ: The occurrence and correction of cobalt and copper deficiency affecting sheep in South Australia. Aust. vet. J. 1950, 26, 152-159.

MacPherson A, Moon FE, Voss RC: Biochemical aspects of cobalt deficiency in sheep with special reference to vitamin status and a possible involvement in the eatiology of cerebral necrosis. Brit. vet. J. 1976, 132, 294-308.

MacPherson A, Gray D, Mitchell GBB, Taylor CN: Ostertagia infection and neutrophil function in cobalt-deficient and cobalt-supplemented cattle. Brit. vet. J. 1987, 143, 348-353.
McLoughlin MF, Rice DA, Taylor SM: Liver lesions resembling ovine white liver disease in cobalt deficient lambs. Vet. Rec. 1984, 115, 325.

Millar KR, Albyt $A T$ : A comparison of vitamin $\mathrm{B}_{12}$ levels in the liver and serum of sheep receiving treatments used to correct cobalt deficiency. $\mathrm{N}$. Z. vet. J. 1984, 32, 105-108.

Mitchell PJ, McOrist S, Thomas KW, McCausland $P$ : White liver disease of sheep. Aust. vet. J. 1982, 58, 181-184.

Quirk $M F$, Norton $B W$ : The Relationship between the Cobalt Nutrition of Ewes and the Vitamin $B_{12}$ status of Ewes and their Lambs. Aust. J. agric. Res. 1987, 38, 1071-1082.

Richard RM, Shumard RF, Pope AL, Phillips PH, Herrick $C A$, Bohnstedt $G$ : The effect of certain mineral supplements on lambs infected with the stomach worm (Haemonchus contortus). $\mathrm{J}$. Anim. Sci. 1954, 13, 694-705.

Richards RB, Harrison MR: White liver disease in lambs. Aust. vet. J. 1981, 57, 565-568.

Smith RM: Cobalt. In: Mertz W (ed.): Trace Elements in Human and Animal Nutrition, vol. 1. Academic Press, London 1987, p. 143-183.

Sutherland RJ: Preliminary observations on the relationship between vitamin $B_{12}$ status and ovine white liver disease. Proc. N. Z. Sheep Soc. 8th Seminar 1978, p. 13-15.

Sutherland RJ, Cordes DO, Carthew GC: Ovine white liver disease - a hepatic dysfunction associated with $B_{12}$ deficiency. N. Z. vet. J. 1979, 27, 227-232.

Ulvund MJ: Kronisk hepatitt hos lam i Norge. Histopatologiske forandringer i leveren. (Chronic hepatitis in lambs in Norway. Histopathology of the liver). Nordisk forening for veterinærpatologi (NFVP), Symposium, Helsinki, 20. -21 . juni 1983. Suomen Eläinlääkärilehti 1983 , $89,314$.

Ulvund MJ: Ovine white-liver disease (OWLD). Clinical pathology. Acta vet. scand. In press a.

Ulvund MJ: Ovine white-liver disease (OWLD). Pathology. Acta vet. scand. In press $b$.

Ulvund MJ: Ovine white-liver disease (OWLD). Serum copper and effects of copper and selenium supplementation. Acta vet. scand. In press c. 
Ulvund MJ, Pestalozzi M: Ovine white-liver disease (OWLD). Botanical and chemical composition of pasture grass. Acta vet. scand. In press.

Ulvund MJ, Øverås J: Chronic hepatitis in lambs, a condition resembling ovine white liver disease in New Zealand. N. Z. vet. J. 1980, 28, 19.

Whitelaw A, Russell AJF: Investigations into the prophylaxis of cobalt deficiency in sheep. Vet. Rec. 1979, 104, 8-11.

Willcock JM: Problems associated with intensively managed grassland. Vet. Rec. 1971, 88, 149152.

\section{Sammendrag}

Kvitleversjuke (kobolt/vitamin $B_{12}$ mangel) hos lam $i$ Norge. Kliniske symptomer og preventive tiltak.

Iløpet av en 6-års periode inngikk 458 Dala- og Rygjalam med mødre $\mathrm{i}$ beiteforsøk for å belyse sjukdommen kvitleversjuke ( $\mathrm{Co} / \mathrm{B}_{12}$-mangel). Grupper av lam gikk på beiter hvor sjukdommen forekommer årvisst, på deler av disse som ble gjødslet med kobolt, eller på kontrollbeiter. Lamma var enten ubehandlet, ble dosert regelmessig med koboltsulfat eller $B_{12}$, ble engangsdosert med koboltpellets, kopperoksydnåler, selenpellets, eller kobolt/selen/kopper glassboli, eller hadde tilgang til kobolt saltslikkestein. De kliniske symptomene omfattet varierende grad av redusert tilvekst og vekttap som viste seg etter 6-12 veker på beitet, når lamma var 10-15 veker gamle. To til fire veker seinere ble lamma likegyldige og uinteresserte i graset, og fikk gjerne serøst øyeflod og småskorper på ørene. $18 \%$ av de ubehandla lamma ble avlivet eller døde pga. sjukdommen, som lot seg forebygge ved tilførsel av kobolt eller $\mathrm{B}_{12}$. Slik tilførsel resulterte $i$ at lamma $i$ gjennomsnitt ble 8-17 kg tyngre i september. Under liknende forhold anbefales koboltgjødsling av beitene, bruk av kobolt slikkestein eller dosering med koboltpellets. Lamma som gikk på kontrollbeitene var $\mathrm{i}$ gjennomsnitt $17 \mathrm{~kg}$ tyngre i september enn dem som gikk på sjukdomsbeitene, men også disse viste noe tilvekstøkning ved ekstra kobolttilførsel.

(Accepted March 10, 1989).

Reprints may be requested from: Martha J. Ulvund, State Veterinary Research Station for Small Ruminants, P. O. Box 264, N-4301 Sandnes, Norway. 